\title{
Acute myeloid leucaemia with trisomy 14 as a sole cytogenetic abnormality
}

\author{
Jeave Reserva, ${ }_{1}^{1}$ Mariver Loleng, ${ }^{2}$ Rachel Marchalik, ${ }^{3}$ Basharath Khan ${ }^{4}$
}

${ }^{1}$ Department of Dermatology, Loyola University Medical

Center, Maywood, Illinois, USA

${ }^{2}$ University of the Philippines

Diliman, Quezon City,

Philippines

${ }^{3}$ Georgetown University School of Medicine, Washington DC, USA

${ }^{4}$ The University of Illinois at Chicago, Chicago, Illinois, USA

\section{Correspondence to}

Dr Jeave Reserva,

jeave.reserva@gmail.com

Accepted 18 September 2015

\section{DESCRIPTION}

Trisomy 14 as a sole cytogenetic abnormality is a rare non-random recurrent change that has been reported in myeloid neoplasms. We report a case of an elderly patient with medical history of coronary artery disease who presented to the emergency department with a history of several weeks of progressively worsening and debilitating fatigue. Complete blood count revealed severe anaemia (haemoglobin, $4.9 \mathrm{~g} / \mathrm{dL}$ ) with macrocytosis (mean corpuscular volume, $113.3 \mathrm{fL}$ ), reticulocytosis (3.1\%) and leucopaenia $(700 / \mu \mathrm{L})$. Peripheral blood smear showed myeloid blasts with few mature neutrophils, erythrocyte macrocytosis with anisocytosis, and normal platelet morphology. A bone marrow biopsy was subsequently performed exhibiting 50\% cellularity with a 20:1 myeloid to erythroid ratio, predominantly consisting of myeloblasts (figures 1 and 2). Normal erythroid and megakaryocytic maturation was noted. A diagnosis of acute myeloid leucaemia (AML) was made, favouring M0 subtype. Cytogenetic analysis revealed isolated trisomy 14 (figure 3). The patient underwent induction chemotherapy with cytarabine and daunorubicin. Unfortunately, he suffered multiple infectious complications during consolidation chemotherapy,

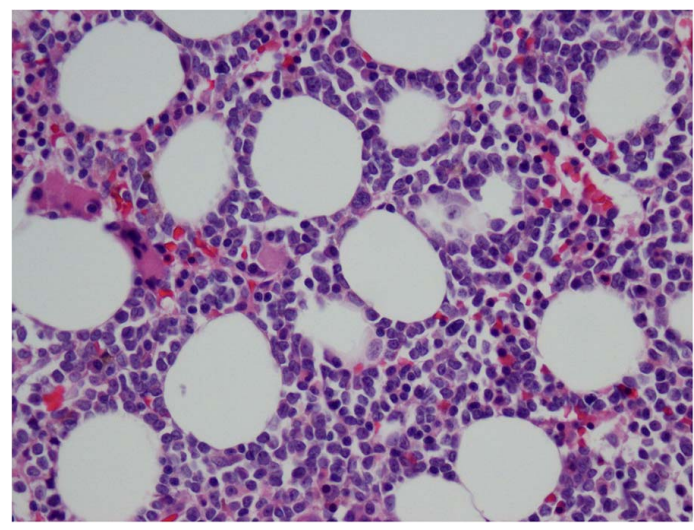

Figure 2 Bone marrow biopsy at high magnification showing myeloblasts as the predominant cell population.

and relapsed, succumbing to the disease 4 months after diagnosis.

Few cases of isolated trisomy 14 in myeloid neoplasms have been reported in the literature, with most observed in myelodysplastic syndromes. ${ }^{1}$ Given its normal erythroid and megarkaryocytic maturation, we posit that the present case arose as a de novo AML, which has not been previously reported. Nevertheless, our case highlights important clinical and prognostic findings in previously
To cite: Reserva J, Loleng M, Marchalik R, et al. BMJ Case Rep Published online: [please include Day Month Year] doi:10.1136/bcr-2015212552

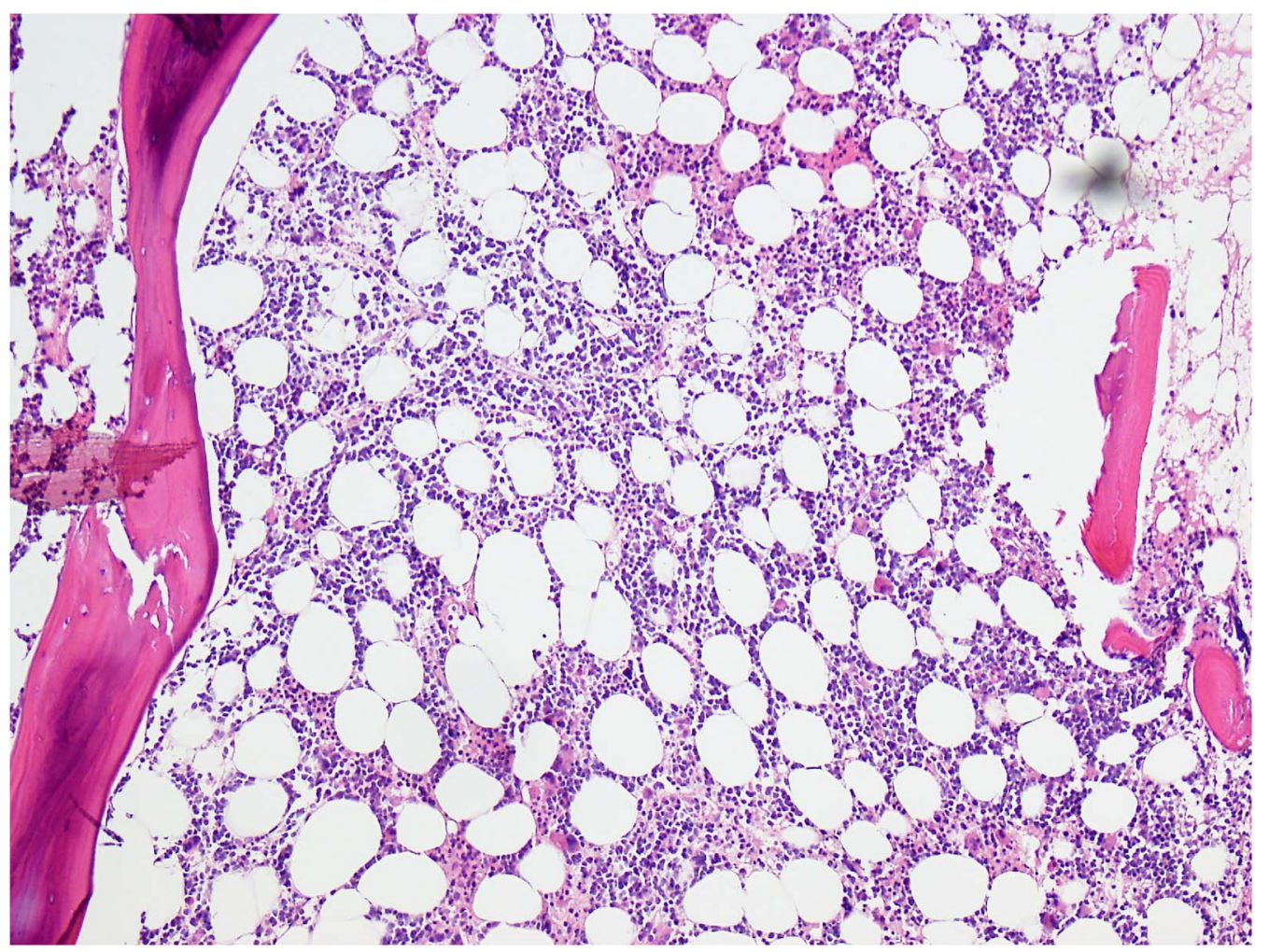

Figure 1 Bone marrow biopsy at low magnification showed 50\% cellularity with a 20:1 myeloid to erythroid ratio. 
Figure 3 Karyotype analysis of tumour tissue revealed trisomy 14 (arrow) as a sole cytogenetic abnormality.

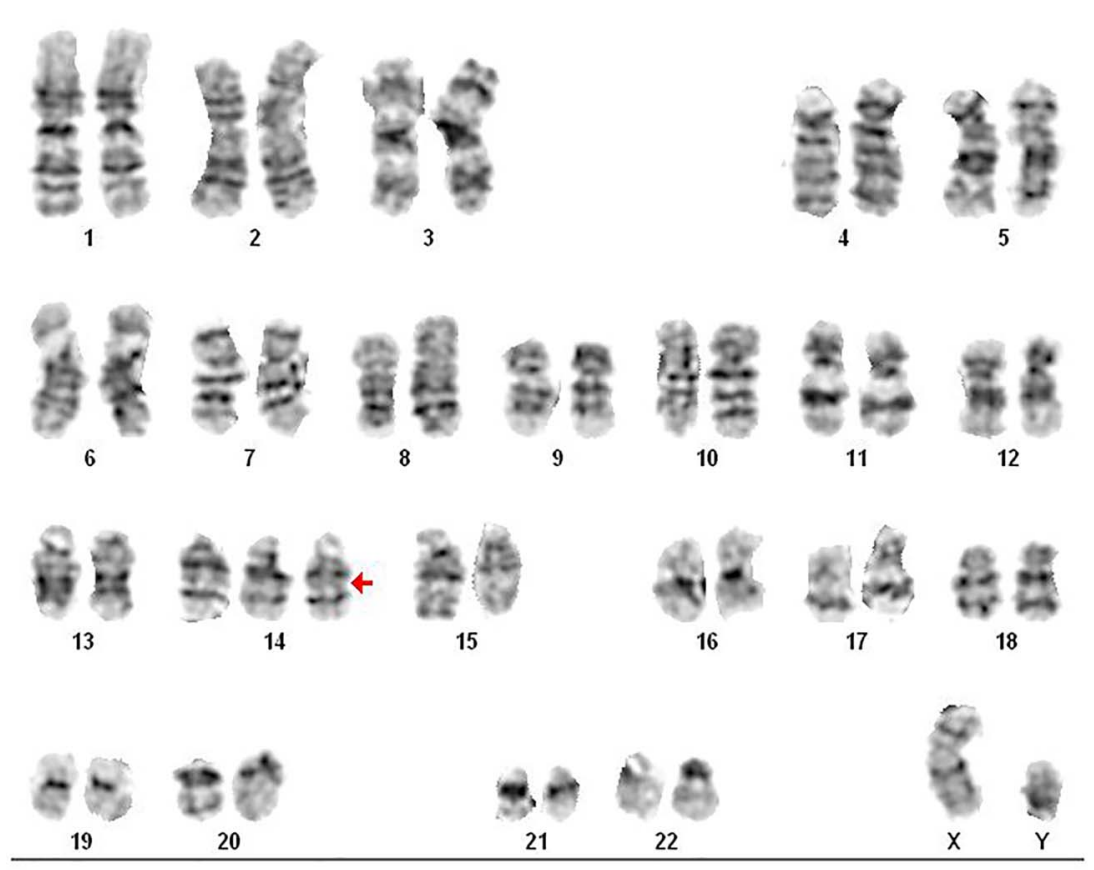

\section{Learning points}

- Trisomy 14 as an isolated chromosomal abnormality is a rare non-random cytogenetic aberration seen most commonly in myelodysplastic syndromes and rarely in cases of acute myeloid leucaemia.

- Although rare, acute myeloid leucaemia with trisomy 14 is often seen in elderly males and has been associated with a short median survival, ranging from 2 to 12 months. reported cases of AML with isolated trisomy 14-elderly male predominance with aggressive disease course.

Competing interests None declared.

Patient consent Not obtained.

Provenance and peer review Not commissioned; externally peer reviewed.

\section{REFERENCE}

1 Cui W, Bueso-Ramos CE, Yin CC, et al. Trisomy 14 as a sole chromosome abnormality is associated with older age, a heterogenous group of myeloid neoplasms with dysplasia, and a wide spectrum of disease progression. J Biomed Biotechnol 2010;2010:365318.

Copyright 2015 BMJ Publishing Group. All rights reserved. For permission to reuse any of this content visit http://group.bmj.com/group/rights-licensing/permissions.

BMJ Case Report Fellows may re-use this article for personal use and teaching without any further permission.

Become a Fellow of BMJ Case Reports today and you can:

- Submit as many cases as you like

- Enjoy fast sympathetic peer review and rapid publication of accepted articles

- Access all the published articles

- Re-use any of the published material for personal use and teaching without further permission

For information on Institutional Fellowships contact consortiasales@bmjgroup.com

Visit casereports.bmj.com for more articles like this and to become a Fellow 